
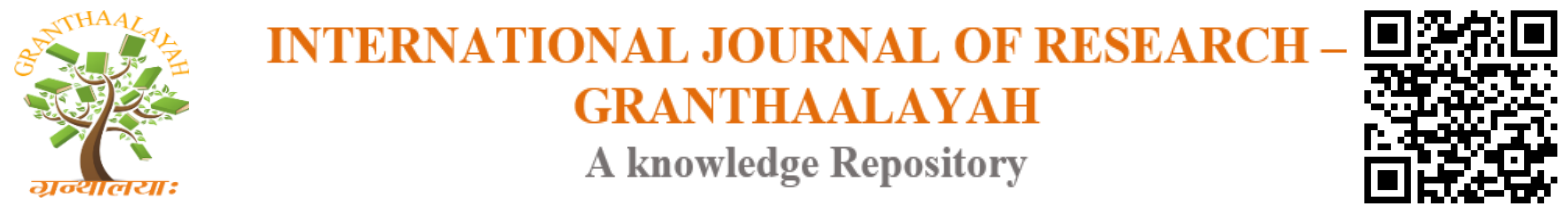

Science

\title{
CONSIDERATIONS OF ANTHROPOMETRICS IN THE DESIGN OF LECTURE HALL FURNITURE
}

\author{
J.O Igbokwe ${ }^{1}$, G. O Osueke ${ }^{1}$, U.V Opara ${ }^{1}$, M. O Ileagu ${ }^{1}$, K.U Ezeakaibeya ${ }^{1}$ \\ ${ }^{1}$ Department of Mechanical Engineering, Federal University of Technology, P.M.B 1526 \\ Owerri, Imo State, Nigeria
}

\begin{abstract}
An anthropometric survey of Federal University of Technology Owerri students was carried out in order to determine the anthropometric data needed for proper design of seats used in the classroom. A total of four hundred students, of different gender and level were involved in the survey and their anthropometric measurement were taken and recorded with the help of anthropometric tools. The anthropometric measurements taken were, Stature, sitting height, sitting shoulder height, Popliteal height, Hip breadth, Elbow rest height, Buttock popliteal length, Buttock knee length, Thigh clearance, Sitting eye height, Shoulder breadth and Knee height. The data obtained were analysed using SPSS, Excel and Minitab statistical packages to get the mean, standard deviation and percentiles. Comparing the dimensions of the existing furniture with the anthropometric measures obtained revealed that the existing furniture are not ergonomically suitable for the students. Using the results of the analysed anthropometric data, a model classroom seat was suggested which takes into consideration the seat height, seat depth, seat width, backrest height, armrest height and backrest angle.
\end{abstract}

Keywords: Anthropmetrics; Ergonomics; Furniture; Measurement; Lecture hall.

Cite This Article: J.O Igbokwe, G. O Osueke, U.V Opara, M. O Ileagu, and K.U Ezeakaibeya. (2019). "CONSIDERATIONS OF ANTHROPOMETRICS IN THE DESIGN OF LECTURE HALL FURNITURE.” International Journal of Research - Granthaalayah, 7(8), 374-386. https://doi.org/10.29121/granthaalayah.v7.i8.2019.686.

\section{Introduction}

Anthropometry is the branch of the human sciences that deals with body measurements: particularly with measurements of body size, shape, strength and working capacity. Anthropometric data is used in ergonomics, to fit the workplace, and tools the man, rather than fit the man to the workplace. The aim is to create a conducive working environment for maximum work efficiency and maximum worker health and safety (Johnsen, et al 2004).

In the university, the lecture halls become the work environment for the students and effort has to be made to ensure that it is comfortable and can allow efficient learning. Hence, the school 
furniture such as chairs and desks are some of the most important facilities in the university since students spend most of their time using them. Considering the amount of time spent at school and specifically while sitting, it is important that school furniture should suit the students' requirements, and it should also allow for the changing of posture (Savanur, et al 2007). Many researchers have tried to establish theoretical recommendations for the principles that relate school furniture design to students' anthropometry, and some have also attempted to define the "appropriate" dimensions for school furniture based on anthropometric measurements. Also, there have been studies related to school furniture design that have investigated differences in body dimensions due to age and gender. In some countries, there were attempts to design desk and chairs based on anthropometric data (Oyewole, et al, 2010).

Thariq et al (2010) observed that chairs are a very essential part of a learning environment. They opined how seats used in the lecture halls are designed, goes a long way to determining if the students will learn comfortably or not and hence recommended that seats must be made to fit the users.

The basic philosophy of ergonomics is to make any design of furniture to lead to comfortability, physical health, safety, well-being, convenient and bring motive towards studies (Tunay \& Melemez, 2008). Students need well-designed furniture due to the incidence that whenever they become confined in an awkward posture while carrying out certain academic activities such as writing, receiving lectures, drawing, reading on desktops, aggravates psychological stress and can impact negatively on the students' performance. According to the study done by Castellucci, et al (2010), a mismatch of seats and the students leads to a drop in the students' learning interest. Also, seats that are poorly designed, especially those that do not consider the anthropometric data of its users, have negative health implications (Metin etal, 2008). This is also buttressed by a study carried out on the anthropometric match in South Africa which it stated that an incorrect body alignment reduces the ability of antigravity muscles to generate torque (Van Niekerk, et al 2013).

It is very essential for an institution of learning to have their own anthropometric measurements regarding students so that it can be used by designers who intend to make ergonomic furniture, for them. This is imperative as it can guarantee comfortability, safety and increased satisfaction level and ultimately reduce Musculoskeletal disorders (MSDs). MSDs are said to be injuries or pain in the joints of the body, muscles, ligaments, tendons, nerves, and structures that support limbs, back and neck. In long run, these MSD which are degenerative diseases and inflammatory conditions can result in pain and impair normal activities of the students (Adu, et al 2014).

Since anthropometric data vary considerably for individuals within a family or a nation and between nations, reliable anthropometric data for a target population are necessary when designing for that population otherwise the product may not be suitable for the users.

Many researchers have proposed numerous methodologies for various furniture designs in the past. Until recently, the design of student chairs has received little or no interest. Ergonomic designs of furniture have been traditionally based on the design of work furniture using the anthropometry and biomechanics of the human body. The main anthropometric measurements that are necessary to determine the dimensions of school furniture that will enable students to maintain correct sitting posture are popliteal height, knee height, buttock to popliteal length and elbow height (Parcells,e 
tal 1999). The main anthropometric dimension and specification used in student furniture design is the popliteal height which determines appropriate seat height. In designing a chair to suit a population, the popliteal height is used to ensure that members of the population are able to sit with their feet supported on the floor, and without undue pressure behind the knees. Likewise, comparing the popliteal height of an individual to the seat height of the available chairs can assist in selecting the most suitable size for that individual. Students run the risk of negative effects from poorly designed and ill-fitting furniture, due to prolonged periods of sitting during school. Grimes \& Legg, (2004), suggested that the combination of bad posture and poor seating coupled with long periods of immobility can lead to the development of lower back pain. Further, they have stated that with expectations and emphasis (in some sectors) on greater educational achievements, the duration of sitting is likely to increase. An uncomfortable sitting posture can lead to health-related consequences, and also the student's learning interest, even during the most stimulating and interesting lessons. Ayoub, (2000) emphasized the need for the feet to be firmly rested on the floor or foot support in order to prevent the thighs from supporting the weight of the lower leg. Literature shows that providing an optimal design solution with sufficient comfort is an extremely difficult task when a fixed-type chair is used. According to Straker, et al (2006), workstations with adjustable seats are favored, since people differ in size and postural preference. Adjustable chairs are preferred for school students or adults, to promote health and comfort in sitting. Further, he stated that seat height adjustability is the most important element of a workstation and is used the most often.

Robinette \& McConville, (1981), urged that a classroom furniture ultimate success depends on how the variations in shape and size of the user population will be accommodated. Toomingas $\&$ Gavhed, (2008) conducted a study of call center operators, and concluded that optimal adjustment of the chair may contribute to less frequent neck/scapulae and back pain. Adjustability of school furniture is an important feature in ensuring equal educational opportunities, increased comfort, and decreased incidence of musculoskeletal symptoms. It is stated that a mismatch between thigh length and seat depth is significantly related to general sitting discomfort, and a mismatch in seated elbow height and desk height is significantly related to reported neck and shoulder pain. HIRA, (1980) after investigating fixed-type university chairs, suggested that the seats should be adjustable. Khanam, et al (2006) evaluated fixed-type university furniture, including a mounted desktop chair, and concluded that students preferred the furniture height to be adjustable Many authors have tried to establish theoretical recommendations for the principles that relate school furniture design to children's anthropometry, and some have also attempted to define the "appropriate" dimensions for school furniture based on anthropometric measurements. Without proper design, sitting will require greater muscular force and control to maintain stability and equilibrium. This, in turn, results in greater fatigue and discomfort and is likely to lead to poor postural habits as well as neck or back complaints. Instead, a one-size-fits-all philosophy has been adopted in the industry, because such furniture is less costly to manufacture and easier to sell at a lower price, and lessens the inventory problems for manufacturers and schools. Existing designs have basically been unaltered for years. Therefore, there is need for ergonomists to treat the issue of furniture design for students as a necessity and educational institutes/universities should treat the selection of right kind of furniture as social responsibility towards the students' community. 


\section{Description of Anthropometric Dimensions.}

According to (Roebuck,1999), the anthropometric dimensions used when designing a classroom seat are:

1) Stature: Top of the head, standing in erect stretched posture. The vertical distance from the floor to the vertex (i.e. the crown of the head).

2) Sitting height: Top of the head sitting in a normal relaxed posture.

3) Sitting shoulder height: Height of uppermost point on the middle level of the shoulder.

4) Popliteal height: Height of the underside of the thigh immediately behind the knee.

5) Hip breadth: Maximum horizontal distance across the hips.

6) Elbow rest height: Distance between the seat and lowermost part of the elbow.

7) Buttock popliteal length: Horizontal distance from the most posterior point on the uncompressed buttocks to the back of the lower leg at the knee.

8) Buttock knee length: Horizontal distance from the most posterior point on the uncompressed buttocks to most anterior point on the knee.

9) Thigh clearance: The vertical distance from the seat surface to the maximum bulge on the anterior surface of the thigh measured with a shortened anthropometer.

10) Sitting eye height: Height of inner corner of the eye sitting in a normal relaxed posture.

11) Shoulder breadth: Maximum horizontal distance across the shoulders.

12) Knee height: Height of uppermost point on the knee.

13) Back Rest Angle: As noted above, research has shown that the best seated posture is a reclined posture of $100^{\circ}-110^{\circ}$. The back rest angle is the angle between the backrest and the seating surface.

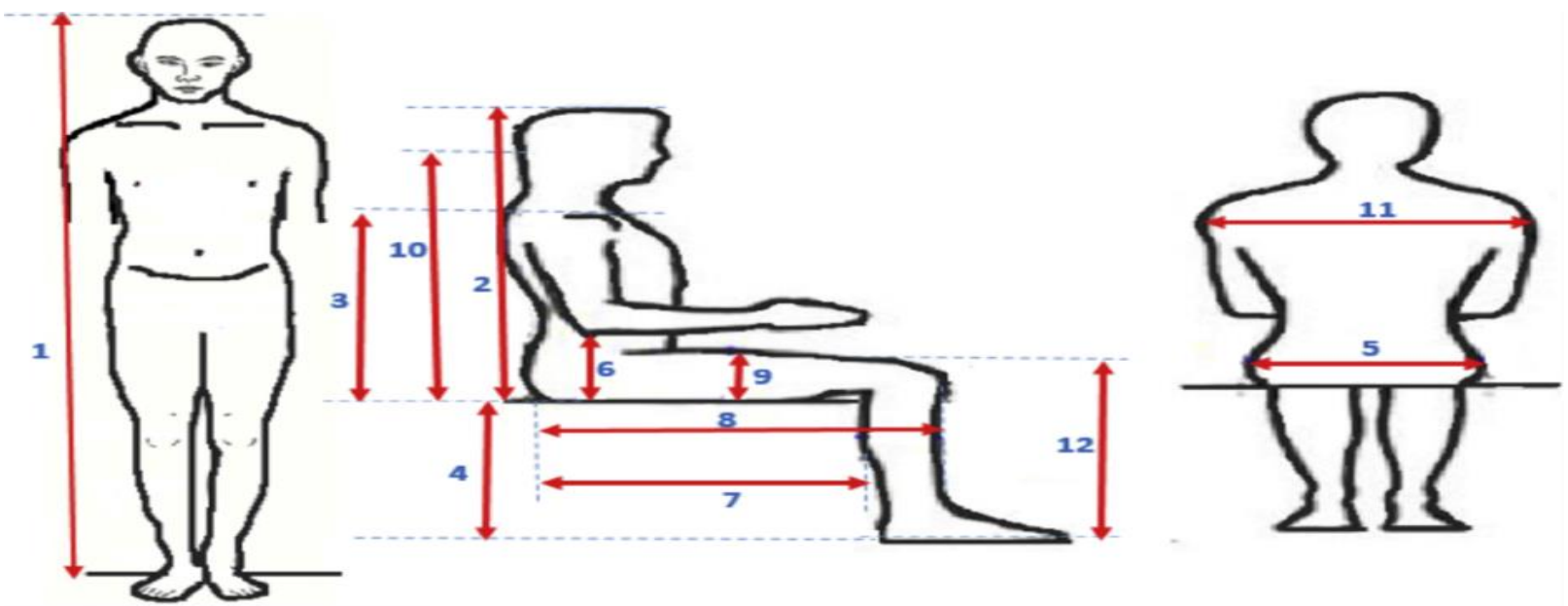

Figure 1: Anthropometric data required in classroom furniture design.

However, actual chair dimensions are determined by measurements of the human body (anthropometric measurements). The two most relevant anthropometric measurement for chair design is the popliteal height and buttock popliteal length.

For someone seated, the popliteal height is the distance from the underside of the foot to the underside of the thigh at the knees. It is sometimes called the "stool height". The term "sitting height" is reserved for the height to the top of the head when seated. The popliteal height, after adjusting for heels, clothing and other issues, is used to determine the height of the chair seat. 
For someone seated, the buttock popliteal length is the horizontal distance from the back most part of the buttocks to the back of the lower leg. This anthropometric measurement is used to determine the seat depth.

Additional anthropometric measurements may be relevant to designing a chair. Research has shown that the best seated posture is a reclined posture of $100^{\circ}-110^{\circ}$ Hedge, (2016). Hip breadth is used for chair width and armrest width. Elbow rest height is used to determine the height of the armrests. The buttock-knee length is used to determine "leg room" between rows of chairs. "Seat pitch" is the distance between rows of seats.

\section{Materials}

In this study the body dimensions were taken using traditional anthropometric tools.

Dimensions were measured using a flexible measuring tape with an accuracy of $0.1 \mathrm{~mm}$, steel ruler for marking the level, non-adjustable plastic chair and plastic ruler. The non-adjustable chair was a plastic seat that had a high back rest for reducing measuring error due to poor gesture of students. It was used to take measurements such as sitting height, shoulder height, etc. Also, the nonadjustable chair had no arm rest which could hinder elbow rest height measurement. The backrest and seat were lined up at right angle to each other and the seat acted as reference point during measurements taking especially in the sitting position. The students' height (stature) was measured using a wall mounted straight ruler with measuring tape attached to it while calibrated in centimeters.

The materials used are:

- A Flexible Measuring Tape: This was used to measure the bodily dimensions.

- Non-adjustable Plastic Chair: This was used to make the subjects sit while measurements were being taken.

- Vernier Calliper (Range 0-300mm with error $\mathbf{0 . 1 m m}$ ): This was used to measure the thigh clearance.

- SPSS: used to carry out statistical analysis of the recorded data.

- Minitab: used to carry out statistical analysis of the recorded data.

- Microsoft Excel: used to record the data.

- Autodesk Inventor: used to design the seat model.

\subsection{Methods}

To carry out this research, different anthropometric measures of the students were taken by adopting proper definitions and standard measuring techniques. 400 students from the Federal University of Technology Owerri were selected to participate in the research. They were randomly drawn from amongst the first through final year students of the institution.

The body size of each student was assessed using standard anthropometric measurement techniques based on study. All anthropometric measures were taken with the subjects wearing their clothes and shoes but as they were dressed for lectures. Measurements were taken every lecture day for 18 days altogether and were done on a level floor in the lecture halls of the subjects in the 
institution. When measuring body dimensions under sitting condition, the subjects were asked to sit in such a way that the upper leg and lower leg remained at right angle to each other. To ensure accuracy and repeatability of measurement, there was practice prior to the data collection session. The measuring instruments were passed through trial runs. The measurements during the trial runs were checked for consistency and accuracy. Also recorded with the measurements are the information regarding the subject's level in the university and sex.

\subsection{Data Analysis}

The collated data were analysed statistically using SPSS 16.0, Minitab and Microsoft Excel (2007) programs. From the anthropometric data, its average, minimum, maximum, variance, standard deviation, 5th percentile, 50th percentile and 95th percentile was extracted. Results of the analysis are shown in Table 1 and Table 2. Only specific parts of the analysed data were used in the design of the classroom furniture. It is worth noting that not all the anthropometric measures are considered in the design of a model classroom seat.

\section{Results and Discussion}

\subsection{Results}

The results obtained from the analysis of the collected data with SPSS, EXCEL and MINTAB software were presented on figures 3 and 4 as well as tables 1 to 5 .

Figure 3 shows the results of the frequency for the major anthropometric parameters while figure 4 presents a bar chart of frequency of the measured parameters.

Tables 1, 2 and 3 shows the descriptive statistics, the percentiles analysis and the average values of the measured parameters. Table 4 show the selected parameters for the suggested ergonomically suited model seat for the students in Federal University of Technology Owerri, and table 5 is the comparison of the data obtained with that of existing classroom seats.

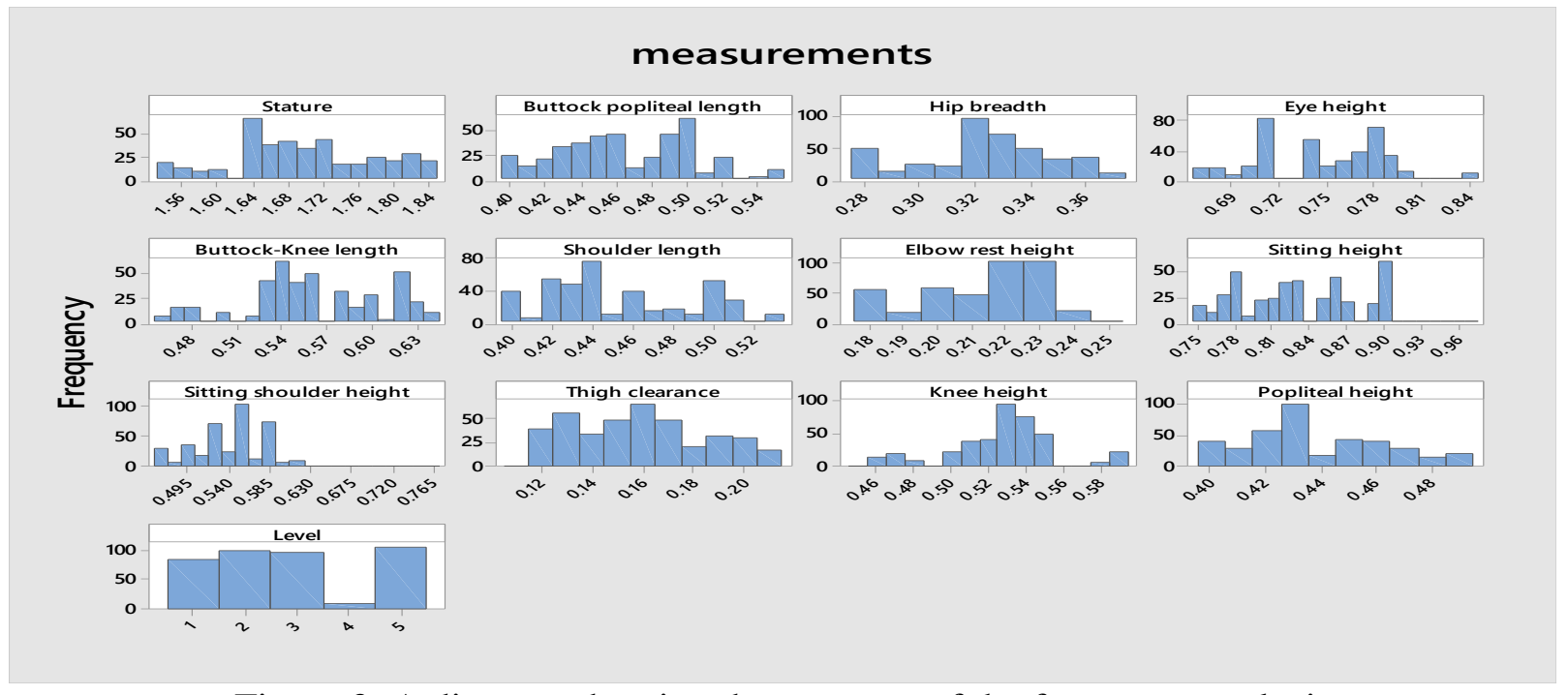

Figure 3: A diagram showing the outcome of the frequency analysis 

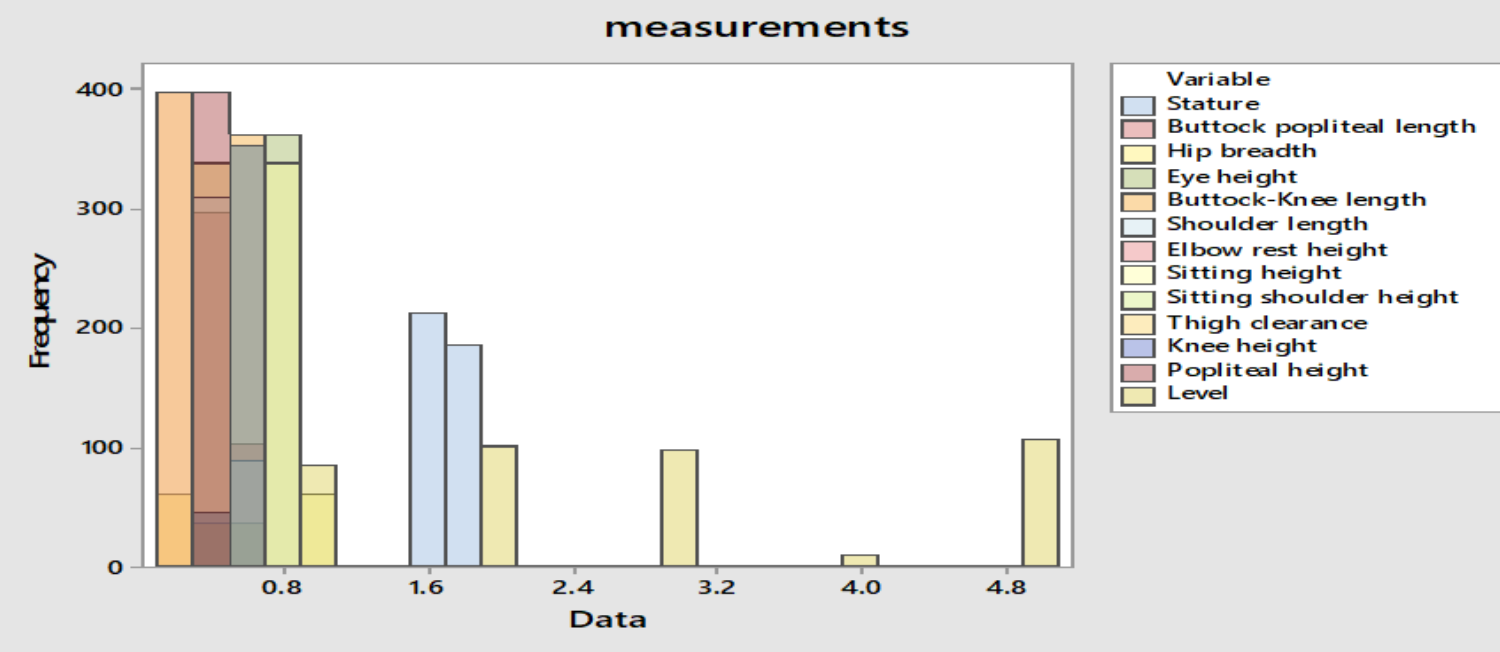

Figure 4: Bar chart of Frequency against Measurement

Table 1 shows the descriptive statistics of the recorded data. These descriptive statistics include the mean, standard deviation, variance, sum, minimum, maximum and range of the entire data collated.

Table 1: Descriptive statistics of the recorded data.

\begin{tabular}{|l|l|l|l|l|l|l|l|l|}
\hline Variable & Mean & St. Dev. & Variance & Sum & Min & Median & Max & Range \\
\hline Stature & 1.6934 & 0.0796 & 0.00633 & 673.9700 & 1.5400 & 1.6900 & 1.8400 & 0.3000 \\
\hline $\begin{array}{l}\text { Buttock } \\
\text { popliteal length }\end{array}$ & 0.46495 & 0.03632 & 0.00132 & 185.0500 & 0.40000 & 0.46000 & 0.55000 & 0.15000 \\
\hline Hip breadth & 0.32377 & 0.02414 & 0.00058 & 128.8600 & 0.28000 & 0.32000 & 0.37000 & 0.09000 \\
\hline Eye height & 0.74598 & 0.03908 & 0.00153 & 296.9000 & 0.67000 & 0.75000 & 0.84000 & 0.17000 \\
\hline $\begin{array}{l}\text { Buttock-Knee } \\
\text { length }\end{array}$ & 0.56136 & 0.04475 & 0.00200 & 223.4200 & 0.46000 & 0.56000 & 0.64000 & 0.18000 \\
\hline Shoulder length & 0.45249 & 0.03567 & 0.00127 & 180.0900 & 0.40000 & 0.44000 & 0.53000 & 0.13000 \\
\hline $\begin{array}{l}\text { Elbow rest } \\
\text { height }\end{array}$ & 0.21304 & 0.01790 & 0.00032 & 84.79000 & 0.18000 & 0.22000 & 0.25000 & 0.07000 \\
\hline Sitting height & 0.83065 & 0.04687 & 0.00220 & 330.6000 & 0.75000 & 0.83000 & 0.97000 & 0.22000 \\
\hline $\begin{array}{l}\text { Sitting shoulder } \\
\text { height }\end{array}$ & 0.54354 & 0.03803 & 0.00145 & 216.3300 & 0.46000 & 0.55000 & 0.77000 & 0.31000 \\
\hline Thigh clearance & 0.15867 & 0.02613 & 0.00068 & 63.15000 & 0.11000 & 0.16000 & 0.21000 & 0.10000 \\
\hline Knee height & 0.52678 & 0.02883 & 0.00083 & 209.6600 & 0.45000 & 0.53000 & 0.59000 & 0.14000 \\
\hline Popliteal height & 0.43786 & 0.02498 & 0.00062 & 174.2700 & 0.40000 & 0.43000 & 0.49000 & 0.09000 \\
\hline
\end{tabular}

Also, the percentile analysis of the recorded data is shown in Table 2 . This percentile analysis took into cognizance, the 5th, 50th and 95th percentile. The percentile analysis is considered in this research in order to accommodate as much persons in the population group as possible.

Table 2: Percentile analysis of the recorded data

\begin{tabular}{|l|l|l|l|}
\hline Variable & 5th Percentile & 50th Percentile & 95th Percentile \\
\hline Stature & 1.5500 & 1.6900 & 1.8300 \\
\hline Buttock popliteal length & 0.4000 & 0.4600 & 0.5200 \\
\hline
\end{tabular}




\begin{tabular}{|l|l|l|l|}
\hline Hip breadth & 0.2800 & 0.3200 & 0.3600 \\
\hline Eye height & 0.6800 & 0.7500 & 0.8000 \\
\hline Buttock-Knee lengths & 0.4700 & 0.5600 & 0.6300 \\
\hline Shoulder length & 0.4000 & 0.4400 & 0.5100 \\
\hline Elbow rest height & 0.1800 & 0.2200 & 0.2400 \\
\hline Sitting height & 0.7600 & 0.8300 & 0.9000 \\
\hline Sitting shoulder height & 0.4700 & 0.5500 & 0.5900 \\
\hline Thigh clearance & 0.1200 & 0.1600 & 0.2000 \\
\hline Knee height & 0.4700 & 0.5300 & 0.5900 \\
\hline Popliteal height & 0.4000 & 0.4300 & 0.4900 \\
\hline
\end{tabular}

Following the results above, Table 3 below gives a summary of the anthropometric measures based on the average of the collated anthropometric data, which can be used in designing a seat for FUTO students:

Table 3: Average of the anthropometric measures

\begin{tabular}{|l|l|}
\hline Stature & 1.6934 \\
\hline Buttock popliteal length & 0.46495 \\
\hline Hip breadth & 0.32377 \\
\hline Eye height & 0.74598 \\
\hline Buttock-Knee length & 0.56136 \\
\hline Shoulder length & 0.45249 \\
\hline Elbow rest height & 0.21304 \\
\hline Sitting height & 0.83065 \\
\hline Sitting shoulder height & 0.54354 \\
\hline Thigh clearance & 0.15867 \\
\hline Knee height & 0.52678 \\
\hline Popliteal height & 0.43786 \\
\hline
\end{tabular}

Table 4: Table showing the values selected and the criteria

\begin{tabular}{|l|l|l|l|}
\hline \multicolumn{1}{|c|}{ Seat feature } & \multicolumn{1}{|c|}{$\begin{array}{c}\text { Anthropometric } \\
\text { measure }\end{array}$} & Design Value & \multicolumn{1}{c|}{ Criteria/Determinant } \\
\hline Seat Height & Popliteal length & 0.438 metres & Average of popliteal height \\
\hline Seat Width & Hip breadth & 0.360 metres & 95th percentile of hip breadth \\
\hline Seat Depth & Buttock-popliteal length & 0.400 metres & $\begin{array}{l}\text { 5th percentile of buttock-popliteal } \\
\text { length }\end{array}$ \\
\hline Back rest width & Hip breadth & 0.360 metres & 95th percentile of hip breadth \\
\hline $\begin{array}{l}\text { Upper seat backrest } \\
\text { height }\end{array}$ & Sitting shoulder height & 0.544 metres & Average of sitting shoulder height \\
\hline $\begin{array}{l}\text { Armrest height/Lower } \\
\text { backrest height }\end{array}$ & Elbow rest height & 0.180 metres & 5th percentile of elbow rest height \\
\hline Backrest angle & & 110 degrees & Literature review suggestion \\
\hline
\end{tabular}

As noted in the introduction to this project work, a survey was carried out on the existing seats in the Federal University of Technology Owerri. In the table below, the results from the survey is listed and compared against the values for the proposed ergonomic seat. 
Table 5: Comparism of existing seat against ergonomically designed seat.

\begin{tabular}{|l|c|c|}
\hline \multicolumn{1}{|c|}{ Seat feature } & $\begin{array}{c}\text { Value from the } \\
\text { existing seat }(\mathbf{m})\end{array}$ & $\begin{array}{c}\text { Value from the ergonomically } \\
\text { designed seat (m) }\end{array}$ \\
\hline Seat Height & 0.400 & 0.438 \\
\hline Seat Width & 0.450 & 0.360 \\
\hline Seat Depth & 0.430 & 0.400 \\
\hline Back rest width & 0.450 & 0.360 \\
\hline Upper seat backrest height & 0.470 & 0.544 \\
\hline Armrest height/Lower backrest height & 0.230 & 0.180 \\
\hline Backrest angle & 90 degrees & 110 degrees \\
\hline
\end{tabular}

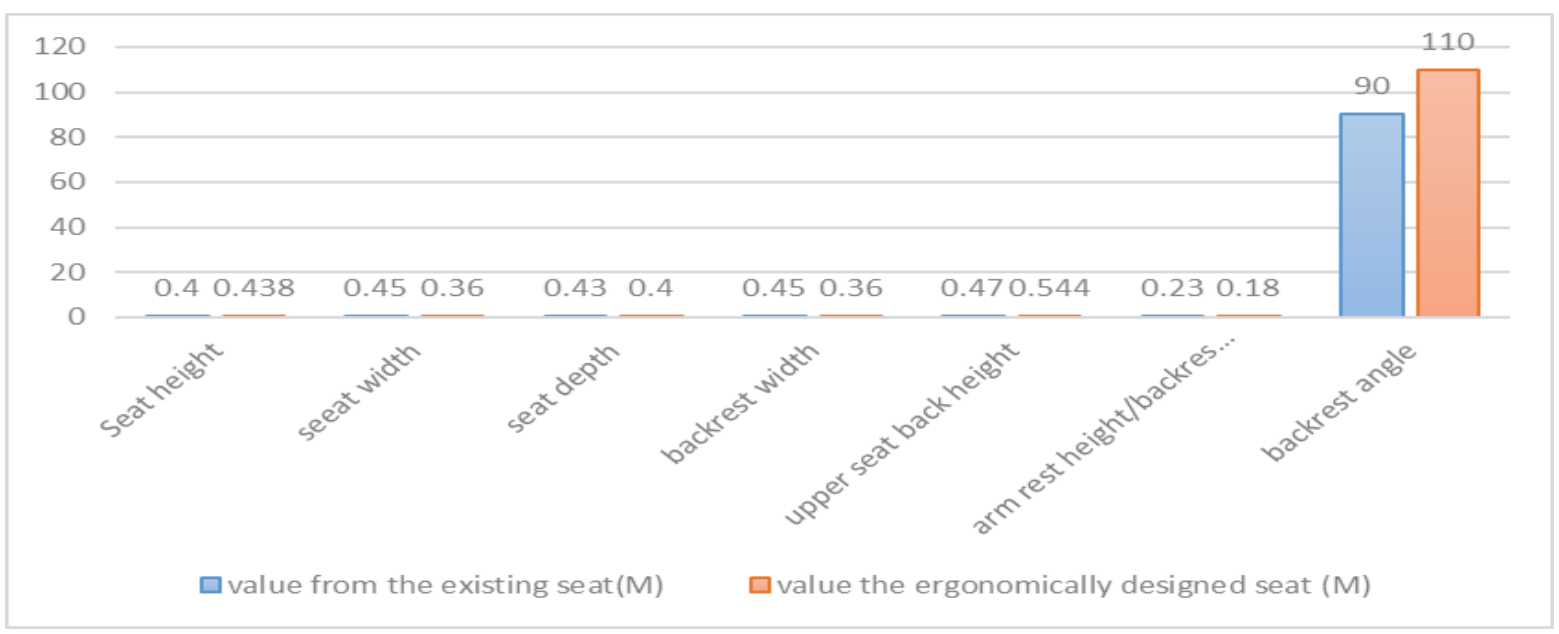

Figure 5: Comparison of existing seat against ergonomically designed seat.

After running the analysis of the recorded data, the model was designed using Autodesk Inventor software with the values and criteria in Table 4. Figure 6 shows the diagrammatic view of the model seat. Also, figure 7 shows the orthographic projection of the model seat and figure 8 shows the exploded view of the seat model.

\subsection{Discussion}

From the analysed results, the anthropometric dimensions for the model classroom seats are presented. The 5th, 50th and 95th percentiles of the various body dimensions as presented in table 2 are considered in the selection of the design values to be used in the model classroom seat design.

\subsection{Considerations for Anthropometric Dimensions for the Design of the Model Classroom Seat.}

\section{Seat Height}

The popliteal height is considered in the design of seat height especially for a seat that cannot be adjusted. The 5th percentile is considered as the maximum seat height allowable. This is to accommodate a larger number of students and give room for short students to use the seat comfortably for a long period of time without being exposed to any health related risk. In this research the 5th percentile for the popliteal height is 0.400 meters., but the average of the 
percentiles is taken to take care of the shoe clearance. Hence 0.438 Meters is used in the design of the seat height.

\section{Seat Depth}

In the design of the seat width, the anthropometric dimension considered is the buttock - popliteal length. The 5th percentile of the buttock - popliteal length is considered to accommodate the shortest user. However, 0.400 Meter is selected seat depth.

\section{Seat Width}

The hip breath is used to determine the seat width. The seat width should be wide enough to accommodate very fat students with their hips and clothing. It should also allow the students to use the seat arms comfortably. The 95th percentile of the seat breath is considered for the design of seat width. For this research, 0.36 Meter is considered.

\section{Arm Rest Angle Height}

The elbow height is considered in the design of the arm rest height. The 5th percentile of the elbow height is considered in the design of the arm rest height. The arm rest height is 0.18 Meter as shown in table 4.

\section{Back Rest Angle}

From available literature, the recommended backrest angle is $110^{\wedge} 0$.

\section{Upper Back Seat Height}

The 5th percentile of the shoulder height is considered in the design of the seat back rest height. 0.544 Meter was considered.

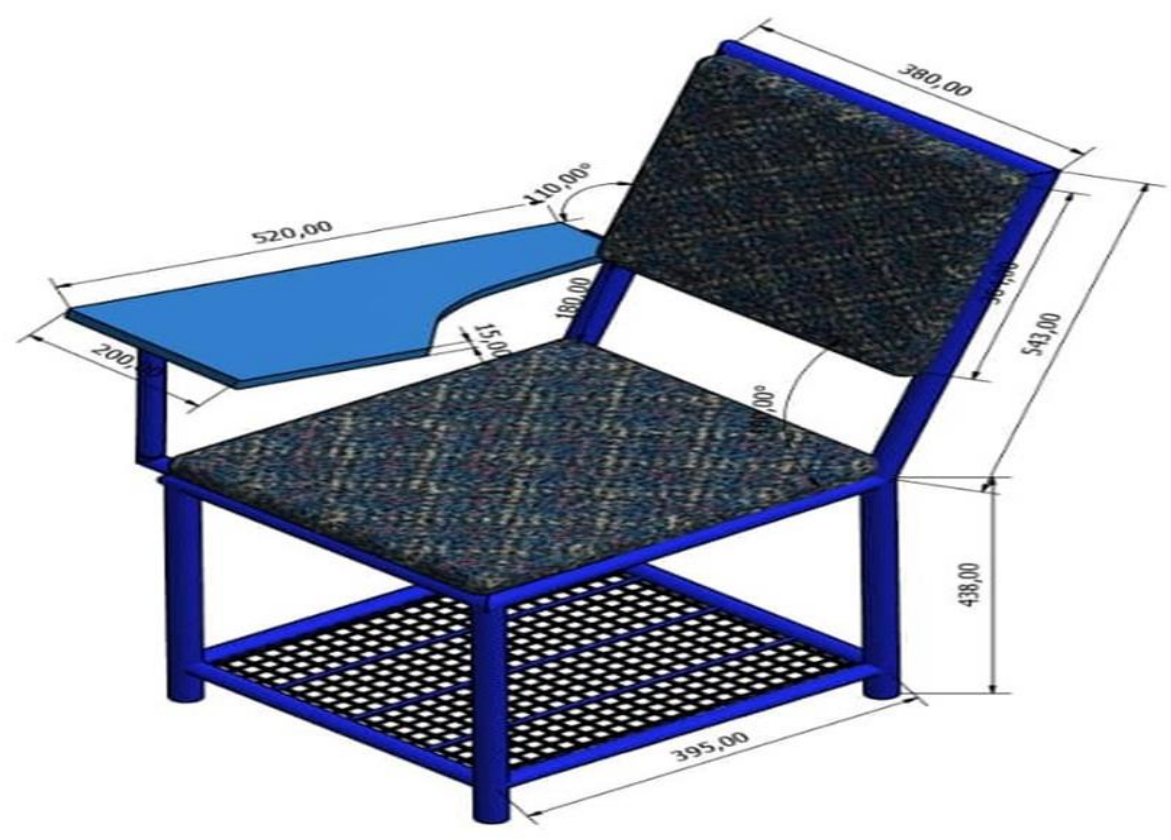

Figure 6: A diagram showing the dimension of the chair based on the average anthropometric data 

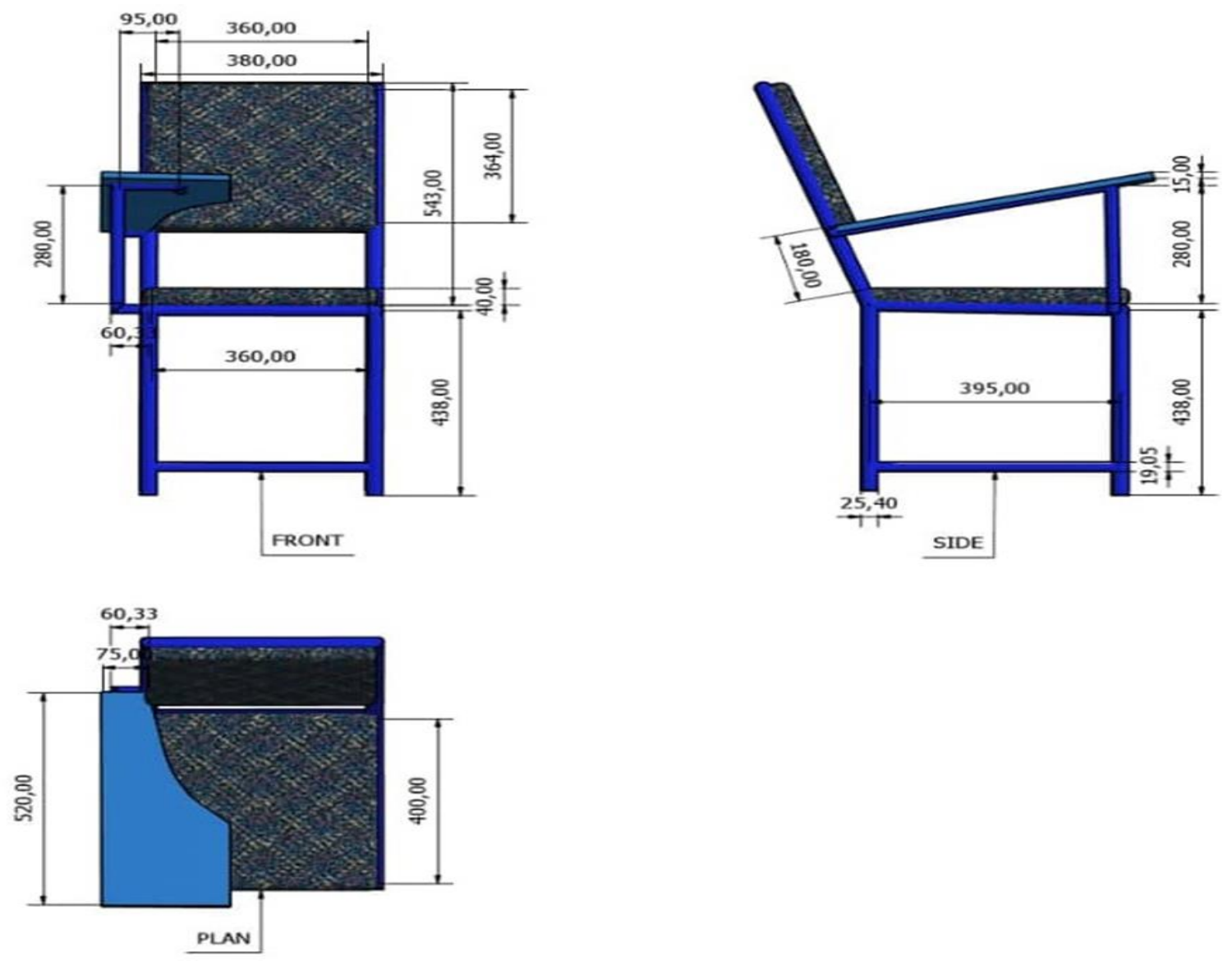

Figure 7: Orthographic projection of the model seat design

STORAGE, SEAT, BACKREST ( $1: 5$ )

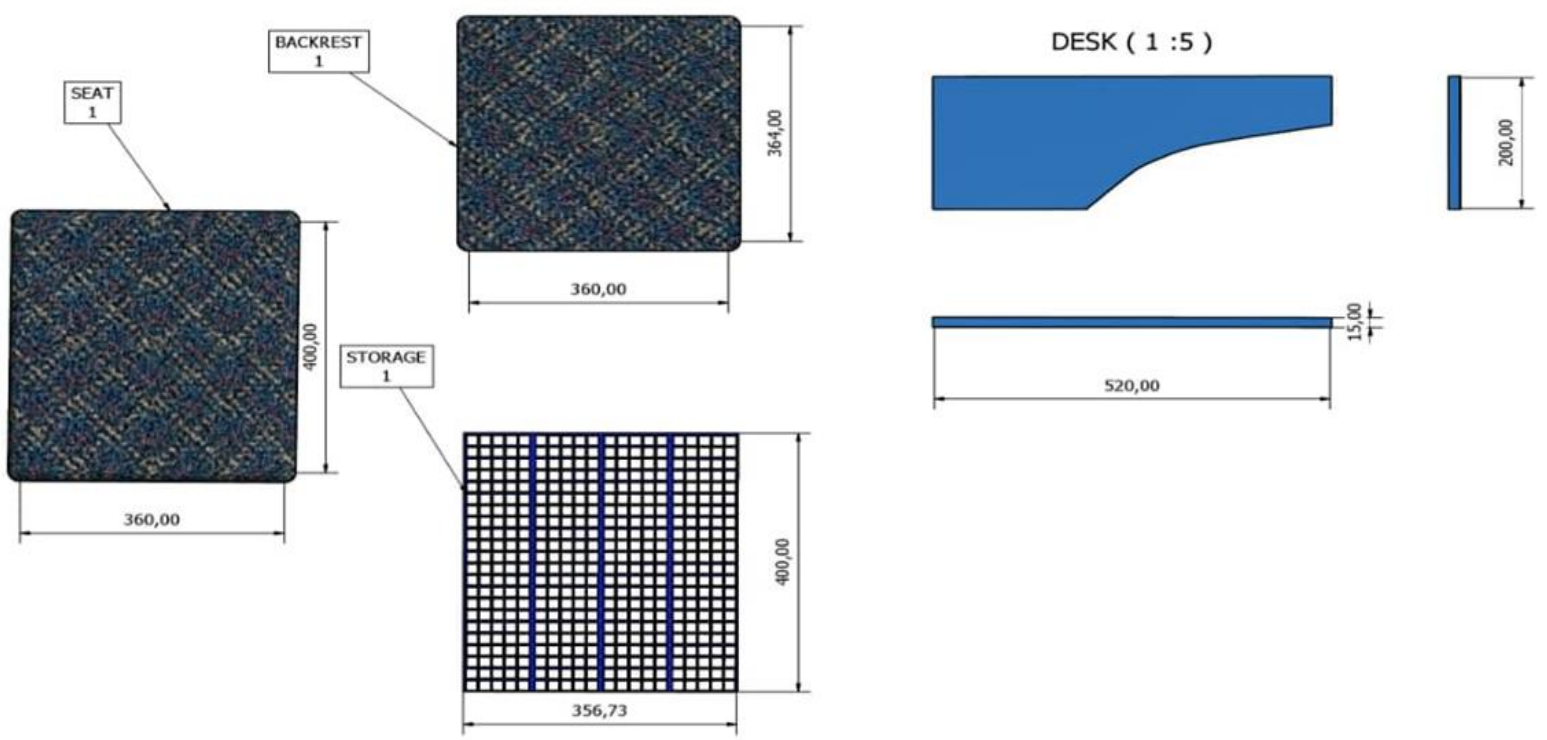

Figure 8: Exploded view of the component par 


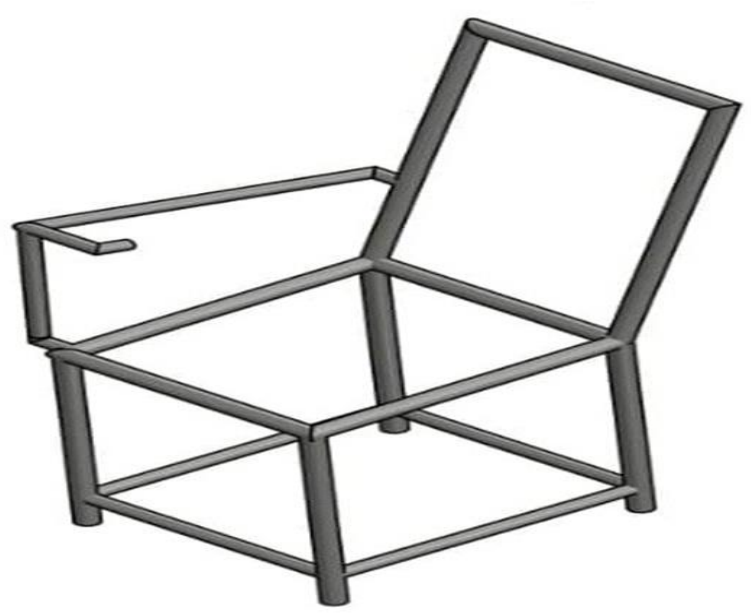

Figure 9: Conceptual framework of the design analysis

\section{Conclusion}

This research is necessary to ensure that the comfort of the students is taken into consideration in the design of classroom furniture. From this research, a model classroom seat was designed which is ergonomically suitable for the students in Federal University of Technology Owerri. It is recommended that the analysed anthropometric data from this research be used for the design of classroom furniture for students in Federal University of Technology, Owerri. Achieving this, will ensure safety, comfort, adaptability, suitability, and ultimately guarantee user satisfaction.

The results from this research shows that the existing university furniture is not compatible with the anthropometric measurements of the students because this furniture were designed by manufacturers without proper considerations of the students' anthropometry.

Lastly, it is recommended that similar study should be carried out in other universities in order to have enough anthropometric data for the design of classroom furniture that are ergonomically friendly for all the institutions of higher learning in Nigeria.

\section{References}

[1] Adu, G., Adu, S., Effah, B., Frimpong-mensah, K., \& Darkwa, N. A. (2014). Office Furniture Design - Correlation of Worker and Chair Dimensions. International Journal of Science and Research (IJSR), 3(3), 709-715.

[2] Ayoub, M. M. (2000). Occupational Biomechanics (3rd ed.) Edited by Don B. Chaffin, Gunnar B. J. Andersson, \& Bernard J. Martin 1999, 579 pages, \$69.96 New York: John Wiley \& Sons, Inc. ISBN: 0-471-24697-2. Ergonomics in Design, 8(3), 33-34. https://doi.org/10.1177/106480460000800311

[3] Castellucci, H.I., Arezes, P.M. and Viviani, C. A. (2010). Mismatch Between Classroom Furniture and Anthropometric Measures in Chilean Schools. Applied Ergonomics, 41, 563-568.

[4] Grimes, P., \& Legg, S. (2004). Musculoskeletal Disorders (MSD) in School Students as a Risk Factor for Adult MSD: A Review of the Multiple Factors Affecting Posture, Comfort and Health in Classroom Environments. Journal of the Human-Environment System, 7(1), 1-9. https://doi.org/10.1618/jhes.7.1

[5] HIRA, D. S. (1980). An ergonomic appraisal of educational desks. Ergonomics, 23(3), 213-221. https://doi.org/10.1080/00140138008924735 
[6] Johnsen, S., Bjørkli, C., \& Steiro, T. (2004). CRIOP®: A scenario method for Crisis Intervention and Operability analysis. Report No. STF38 ....

[7] Khanam, C. N., Reddy, M. V, \& Mrunalini, a. (2006). Opinion of Students on Seating Furniture Used in Classroom. Journal of Human Ecology, 20(1), 15-20.

[8] Metin Tunay and Kenan Melemez. (2008). An analysis of biomechanical and anthropometric parameters on classroom furniture design. African Journal of Biotechnology, 7(8), 1081-1086.

[9] Parcells, C., Stommel, M., \& Hubbard, R. P. (1999). Mismatch of classroom furniture and student body dimensions: Empirical findings and health implications. Journal of Adolescent Health, 24(4), 265-273. https://doi.org/10.1016/S1054-139X(98)00113-X

[10] Oyewole, S. A., Haight, J. M., \& Freivalds, A. (2010). The ergonomic design of classroom furniture/computer work station for first graders in the elementary school. International Journal of Industrial Ergonomics, 40(4), 437-447. https://doi.org/10.1016/j.ergon.2010.02.002

[11] Roebuck, J. A. (1999). Indian Anthropometric Dimensions for Ergonomic Design Practice By Debkumar Chakrabarti 1997, 161 pages, Rs 1500.00 (approx. US\$35.34) Paldi, Ahmedabad, India: National Institute of Design ISBN 81-86199-15-0. Ergonomics in Design, 7(2), 37. https://doi.org/10.1177/106480469900700210

[12] Robinette, K. M., \& McConville, J. T. (1981). An Alternative to Percentile Models. SAE International. https://doi.org/10.4271/810217

[13] Savanur, C. S., Altekar, C. R., \& De, A. (2007). Lack of conformity between Indian classroom furniture and student dimensions: proposed future seat/table dimensions. Ergonomics, 50(10), 1612-1625. https://doi.org/10.1080/00140130701587350

[14] Straker, L., Pollock, C., \& Burgess-Limerick, R. (2006). Towards evidence-based guidelines for wise use of computers by children. International Journal of Industrial Ergonomics, 36(12), 10451053. https://doi.org/10.1016/j.ergon.2006.09.006

[15] Thariq, M. G. M., Munasinghe, H. P., \& Abeysekara, J. D. (2010). Designing chairs with mounted desktop for university students: ergonomics and comfort. International Journal of Industrial Ergonomics, 40(1), 8-18.

[16] Toomingas, A., \& Gavhed, D. (2008). Workstation layout and work postures at call centres in Sweden in relation to national law, EU-directives and ISO-standards, and to operators' comfort and symptoms. International Journal of Industrial Ergonomics, 38(11-12), 1051-1061. https://doi.org/10.1016/j.ergon.2008.02.010

[17] Van Niekerk, S.-M., Louw, Q. A., Grimmer-Somers, K., Harvey, J., \& Hend.

\footnotetext{
*Corresponding author.

E-mail address: osueke2009@ yahoo.com
} 